\title{
Epic landslide erosion from mountain roads in Yunnan, China - challenges for sustainable development
}

\author{
R. C. Sidle ${ }^{1, *}$, M. Ghestem ${ }^{2}$, and A. Stokes ${ }^{3}$ \\ ${ }^{1}$ US Environmental Protection Agency, Ecosystems Research Division, National Exposure Research Laboratory, ORD, \\ 960 College Station Road, Athens, GA 30605, USA \\ ${ }^{2}$ ONCFS, CNERA PAD, 5 allée de Bethléem, 38610 Gières, France \\ ${ }^{3}$ French National Institute for Agricultural Research (INRA), AMAP, Bld de la Lironde, 34398 Montpellier CEDEX 5, France \\ * current at address: University of the Sunshine Coast, Sustainability Research Centre, Locked Bag 4, \\ Maroochydore, QLD 4558, Australia \\ Correspondence to: R. C. Sidle (rsidle@usc.edu.au)
}

Received: 10 April 2014 - Published in Nat. Hazards Earth Syst. Sci. Discuss.: 3 June 2014

Revised: - - Accepted: 13 October 2014 - Published: 27 November 2014

\begin{abstract}
Expanding systems of mountain roads in developing countries have significantly increased the risk of landslides and sedimentation, and have created vulnerabilities for residents and aquatic resources. We measured landslide erosion along seven road segments in steep terrain in the upper Salween River basin, Yunnan, China and estimated sediment delivery to channels. Landslide erosion rates along the roads ranged from 2780 to $48235 \mathrm{Mg} \mathrm{ha}^{-1} \mathrm{yr}^{-1}$, the upper end of this range being the highest rate ever reported along mountain roads. The two roads with the highest landslide erosion $\left(\mathrm{FG} 1=12966 \mathrm{Mg} \mathrm{ha}^{-1} \mathrm{yr}^{-1} ; \mathrm{DXD}=48235 \mathrm{Mg} \mathrm{ha}^{-1} \mathrm{yr}^{-1}\right.$ ) had some of the highest sediment delivery rates to channels (about 80 and 86\%, respectively). Overall, 3 times more landslides occurred along cut slopes compared to fill slopes, but fill slope failures had a combined mass $>1.3$ times that of cut slope failures. Many small landslides occurred along road cuts, but these were often trapped on the road surface. Given the magnitude of the landslide problem and the lack of attention to this issue, a more sustainable approach for mountain road development is outlined based on an analysis of landslide susceptibility and how thresholds for landslide trigger mechanisms would be modified by road location and different construction techniques.
\end{abstract}

\section{Introduction}

Although there is ample evidence of the effects of mountain road development on landslide initiation, only recently has this issue been raised within the context of sustainable development and the potential collapse of certain ecosystem functions (Sidle and Ziegler, 2012; Sidle et al., 2013). In particular, the extent of environmental damage caused by landslides along mountain roads in developing nations is poorly understood. While numerous international donors, non-governmental organizations (NGOs), and environmental advocates have attributed increased sedimentation in rivers and streams in these regions to shifting cultivation and deforestation (e.g., UNESCO, 1974; Eckholm, 1979; Volk et al., 1996; Marshall, 1999), more comprehensive investigations and analyses recognize that these land use practices exert much less influence on downstream sediment and aquatic resources than poorly constructed mountain roads (Sidle et al., 2006, 2007, 2011; Wasson et al., 2008; Ziegler et al., 2009). Of course, road and trail systems are associated with shifting cultivation and deforestation, but more recent, rapid expansion of road networks in mountainous terrain of developing nations have been linked to transitions from shifting cultivation to more intense agriculture, increased tourism, economic development, national defense, emergency evacuation routes, and hydropower development (Krongkaew, 2004; Nyaupane et al., 2006; Ziegler et al., 2012; Urban et al., 2013). Rural road development in Southeast Asia has been aggressively 
supported by organizations such as the Asian Development Bank, the Food and Agricultural Organization of the United Nations, and the World Bank, largely based on perceived socioeconomic benefits (van de Walle, 2002; Balisacan, 2005; Hettige, 2006). In most cases, long-term sustainability assessments that weigh the relative benefits and impacts of rural mountain roads, including socioeconomic tradeoffs, have not been conducted (Sidle et al., 2013).

Any road constructed in steep terrain will decrease the stability of the hillslope (Sidle and Ochiai, 2006). Roads cut into steep slopes promote landslides by removing upslope support and oversteepening the cut slope (Megahan et al., 1978; Rice, 1999; Sidle et al., 2006). Fill slopes, particularly when excavated fill material is poorly compacted, are susceptible to failure due to overloading and oversteepening of the slope, as well as when road drainage concentrates on these sites (Burroughs et al., 1976; Douglas et al., 1999; Sidle et al., 2011). As such, mid-slope mountain roads tend to create the most severe landslide problems because they experience both cut-and-fill failures including intercepting substantial quantities of subsurface water which often triggers landslides in fill slopes (Wemple et al., 2001; Sidle and Ochiai, 2006). If the terrain below these mid-slope roads is steep, much of the landslide material can directly reach streams or rivers, contributing significantly to sedimentation (Mills, 1997; Sidle et al., 2011). Because a significant portion of new rural road construction in northern Yunnan, China, as well as throughout developing regions of Southeast and East Asia, is occurring in steeply dissected mountainous regions, the associated landslides and sedimentation are problematic (Nyaupane et al., 2006; Wasson et al., 2008; Sidle and Ziegler, 2012). However, such land management effects have not been well documented, particularly with regard to sediment sources and delivery. A recent empirical assessment of the combined effects of structural control measures, vegetation restoration, and climate change on reduction of suspended sediment in the Kejie catchment within Yunnan noted that the former two practices were most effective in reducing suspended sediment (Ma et al., 2014); however, road inputs were not assessed in this study and the model used in the analysis (SWAT) has been clearly shown to ignore mass wasting contributions and produces erroneous sedimentation estimates in unstable terrain (Sidle, 2006).

Structural measures to prevent landslides along roads have been used effectively in vulnerable sites (e.g., Holtz and Schuster, 1996) but are prohibitively expensive in remote regions of most developing countries (Sidle and Ochiai, 2006). Check dams in streams and rivers can effectively remove sediment (Ma et al., 2014), but are expensive and do not address problems at the source or in upstream reaches, and are not sustainable control measures. Furthermore, little attention has been paid to road location and construction techniques in mountainous Southeast Asia (Sidle et al., 2004, 2006, 2011; Ziegler et al., 2004, 2012). As such, landslide issues need to be more carefully considered by many of the agencies that initiate and control the construction of such corridors in developing nations, as well as environmental groups and international organizations, which are focusing more on widespread land cover changes and hydropower development (Sidle and Ochiai, 2006; Tullos et al., 2013).

One of the first instances of heightened environmental awareness of road-related landslides was associated with sedimentation of streams and resultant impacts on fish habitat in the Pacific Northwest, USA during the 1970s and 1980s. Rates of landslide erosion from secondary forest roads in unstable terrain of Oregon and Washington ranged from 25 to $155 \mathrm{Mg} \mathrm{ha}^{-1} \mathrm{yr}^{-1}$ (Sidle et al., 1985). These impacts were believed to be significant enough to severely curtail logging of forests on government lands in this region. Prior to this time, the major stability concerns with mountain roads focused on road closure, repair costs, and the maintenance needed to retain access (e.g., Bansal and Mathur, 1976; Chassie and Goughnour, 1976; Fleming and Taylor, 1980).

Little emphasis has been placed on the impacts of landslides on environmental health and human welfare in developing countries of Asia where secondary mountain road systems are expanding at a rapid pace (Haigh, 1984; Sakakibara et al., 2004; Castella et al., 2005). Within China, the total road length of rural transportation networks increased by 5.5fold during the 30-year period from 1978 through the end of 2007 (China Road Construction Report, 2008). A recent study (Sidle et al., 2011) that reported extremely high levels of landslide erosion (1410-33,450 $\mathrm{Mg} \mathrm{ha}^{-1} \mathrm{yr}^{-1}$ ) along a recently constructed road in the Mekong River basin of Yunnan, China, as well as observations of similar and prolific landslide problems in the upper Salween and Jinsha River basins of Yunnan Province, encouraged us to examine this issue in greater detail and across a wider range of mountain roads. Herein, we present comprehensive landslide measurements at five general locations (with a total of seven road segments) within the Salween River basin of northern Yunnan, China, as well as estimates of the delivery of landslide sediment to streams and rivers. This study aims to provide a quantitative basis for government and local planning agencies, international donors, and conservation groups to focus their priorities and efforts related to mountain road expansion, location, and construction. Additionally, we show how this information can be used in sustainability assessments for mountain ecosystems subject to these development pressures.

\section{Site considerations}

The steep Hengduan Mountains of western Yunnan Province are currently experiencing rapid development pressures due to the opening of access to remote villages, hydropower development, agriculture, tourism, forest exploitation, and other related aspects of economic development. This area includes the north-south trending, deeply dissected gorges 
of the "three great rivers" (i.e., Salween, Mekong, and Jinsha rivers) within "The Three Parallel Rivers of Yunnan Protected Areas", inscribed by UNESCO on the World Heritage List in 2003 based on their unique geological history, geomorphic features, ecological processes, and rich biodiversity (UNESCO, 2003). The Salween River (known as the Nujiang in China) originates in the Tibetan Plateau and winds down steep gorges in northern Yunnan, along the border of southern Myanmar and northwestern Thailand, and eventually discharges into the Andaman Sea off the coast of Myanmar some $2800 \mathrm{~km}$ downriver. In our study region of northwestern Yunnan, the Salween River follows a major seismic fault. While considered to be one of the poorest regions in China (Su et al., 2012), the rapid anthropogenic change in this area is causing numerous impacts on the landscape and river systems.

The seven road segments we surveyed for landslide erosion are located in five general locations along the Salween River in a region spanning about $120 \mathrm{~km}$ from $26^{\circ} 01^{\prime} \mathrm{N}$, $98^{\circ} 50^{\prime} \mathrm{E}$ in the south to $27^{\circ} 05^{\prime} \mathrm{N}, 98^{\circ} 52^{\prime} \mathrm{E}$ at the northernmost site (Fig. 1). All roads were unpaved and unimproved with no drainage facilities, typical of such secondary corridors in this region. From south to north, the five survey areas for unimproved roads are (1) a newly constructed road to access remote mountain villages and a hydropower plant along a tributary of the Salween River just south of Daxingdi village (DXD); (2) two segments of a recently widened road to provide access to remote mountain villages near the Salween River about $40 \mathrm{~km}$ south of Fugong (SFG1 and SFG2; lower portion of the road, SFG2, accessed a hydropower plant as well); (3) a relatively new and incomplete road to a small mountain village near Ganxiangke (GXK); (4) two segments of a recently widened road to access small mountain villages near the Salween River several kilometers north of Fugong (FG1 and FG2); and (5) a short road used for sand excavation from the Salween River near Wa Tu Wa village (WTW). All surveyed road segments were at mid-slope locations requiring excavation into the hillsides. These roads were recently constructed or widened, and the approximate dates of the construction were obtained from interviews with residents at each site for corroboration (Table 1). Except for the very short $(0.19 \mathrm{~km})$ road segment into the sand quarry near Wa Tu Wa (WTW), individual surveyed road segments ranged in length from 0.75 to $0.86 \mathrm{~km}$. Details of the road survey sites are given in Table 1.

Elevations in the general study area range from about 800 to $>3000 \mathrm{~m}$; elevations at surveyed road sites ranged from about 990 to $1450 \mathrm{~m}$. The region is within an active orogenic belt, where the compression of the Eurasian plate by the underlying Indian plate gives rise to the high mountains, steep and incised gorges, and deeply incised river channels. With progressive uplifting and associated shearing, the Salween River continues to incise creating steep slopes proximate to the main channel and many tributaries. To the west of the river, the Gaoligong magmatic belt and high-grade
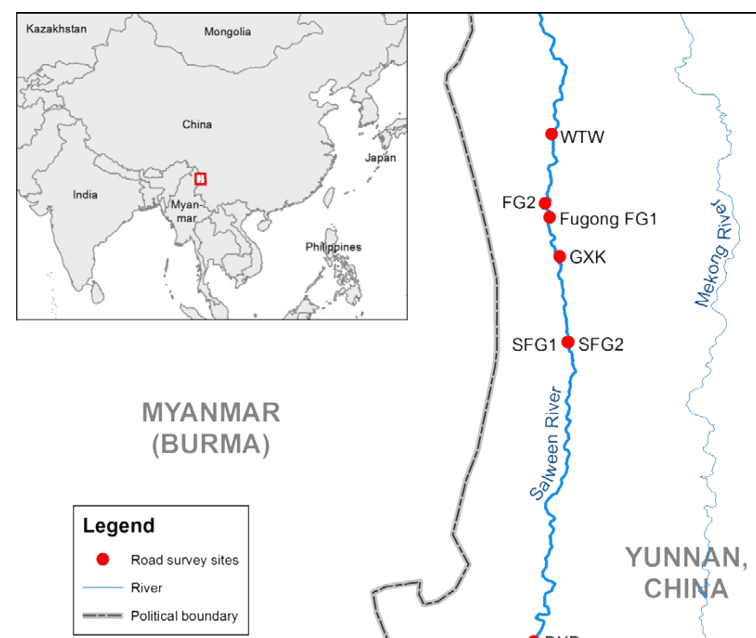

MYANMAR (BURMA)
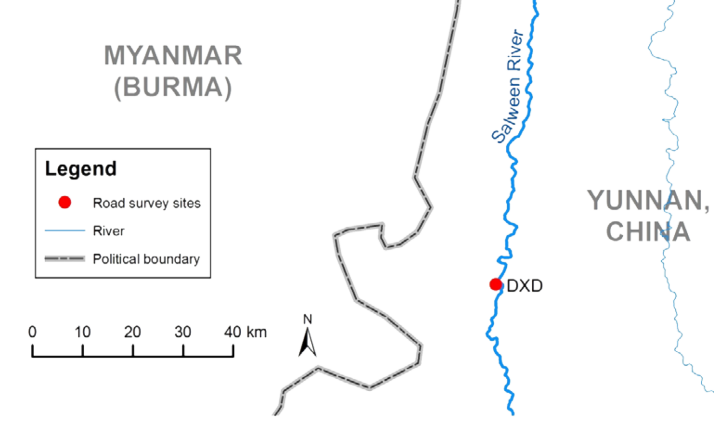

Sources: @2010 Esri. World Countries, 2010-06-30; @2010 DeLorme, Esri. World Linear Water, 2010-06-30

Figure 1. Map showing the general locations of the road survey segments within the Salween River basin. Given the recent construction of these unpaved mountain roads, no road network map is available. The map in the upper left corner shows the general location of the study area within China and the greater Asian region.

metamorphic rocks are aligned with the north-south trending Gaoligong Mountains. East of the river, gneissic granite with included biotite, amphibolites, and muscovite occur in highly sheared contacts within meta-sedimentary rocks (Song et al., 2007).

Terrain that is undisturbed experiences limited landslide activity as does land cultivated by traditional agricultural practices. Only in the higher elevations on very steep slopes do significant numbers of surficial mass movements occur in relatively unmanaged terrain; these areas are typically remote from active channels. No major earthquakes occurred in the 5 -year period prior to our field survey. Because of heavy seasonal rainfall, the steep nature of the terrain, the proximity of hillslopes to the Salween River (or its tributaries), and the highly altered bedrock, secondary roads cut into these hillsides are highly unstable. Whilst the types of igneous, metamorphic, and sedimentary rocks vary somewhat among and within the different road sites, the dominant feature that characterized bedrock failures is the highly fractured nature of the exposed rock. Based on our field experience, soil development over bedrock varies in depth from a few decimeters to several meters in some cases, depending on slope position and microtopography.

This part of China is under the influence of the Indian monsoon, and described as a "warm-dry climate", being a combination of subtropical and alpine climates. Annual mean temperature (average from 1961 to 2010 ) is $20.2^{\circ} \mathrm{C}$, 
Table 1. Geographic information and landslide erosion data for the seven road segments surveyed in northwestern Yunnan.

\begin{tabular}{|c|c|c|c|c|c|c|c|c|c|c|c|}
\hline \multirow{3}{*}{$\begin{array}{l}\text { Road } \\
\text { description/ } \\
\text { general } \\
\text { location }\end{array}$} & \multirow[t]{3}{*}{$\begin{array}{l}\text { Latitude/ } \\
\text { longitude }\end{array}$} & \multirow{3}{*}{$\begin{array}{r}\text { Average } \\
\text { elevation } \\
(\mathrm{m})\end{array}$} & \multirow{3}{*}{$\begin{array}{l}\text { Road } \\
\text { age } \\
\text { (years) }\end{array}$} & \multirow{3}{*}{$\begin{array}{l}\text { Surveyed } \\
\text { road } \\
\text { length } \\
(\mathrm{m})\end{array}$} & \multirow{3}{*}{$\begin{array}{l}\text { Avg. } \\
\text { road } \\
\text { width } \\
(\mathrm{m})\end{array}$} & \multicolumn{2}{|c|}{$\begin{array}{l}\text { Landslide depth } \\
\text { (m) }\end{array}$} & \multirow{2}{*}{\multicolumn{2}{|c|}{$\begin{array}{l}\text { Gradient } \\
\text { proximate to } \\
\text { landslides }\left(^{\circ}\right)\end{array}$}} & \multirow{3}{*}{$\begin{array}{l}\text { Landslide } \\
\text { erosion } \\
\left(\mathrm{Mg} \mathrm{ha}^{-1}\right. \\
\mathrm{yr}^{-1}\end{array}$} & \multirow{3}{*}{$\begin{array}{l}\text { Sediment } \\
\text { delivery } \\
\text { estimates }\end{array}$} \\
\hline & & & & & & Range & Avg. & & & & \\
\hline & & & & & & & & Range & Avg. & & \\
\hline $\begin{array}{l}\text { Hydropower } \\
\text { road, } 1 \mathrm{~km} \\
\text { south of } \\
\text { Daxingdi DXD }\end{array}$ & $\begin{array}{l}26^{\circ} 01^{\prime} 20^{\prime \prime} \mathrm{N} \\
98^{\circ} 50^{\prime} 32^{\prime \prime} \mathrm{E}\end{array}$ & 990 & 1 & 862 & 7.28 & $0.3-2.8$ & 1.24 & $38-71$ & 48.6 & 48238 & $86 \%$ \\
\hline $\begin{array}{l}\text { Sand quarry } \\
\text { road near WA } \\
\text { Tu Wa village } \\
\text { WTW }\end{array}$ & $\begin{array}{l}27^{\circ} 05^{\prime} 58^{\prime \prime} \mathrm{N} \\
98^{\circ} 52^{\prime} 14^{\prime \prime} \mathrm{E}\end{array}$ & 1228 & 1.5 & 186 & 5.09 & $0.2-2.0$ & 0.64 & $29-68$ & 46.3 & 3458 & $82 \%$ \\
\hline $\begin{array}{l}\text { Village road } \\
\text { near } \\
\text { Ganxiangke } \\
\text { GXK }\end{array}$ & $\begin{array}{l}26^{\circ} 50^{\prime} 18^{\prime \prime} \mathrm{N} \\
98^{\circ} 53^{\prime} 06^{\prime \prime} \mathrm{E}\end{array}$ & 1448 & 1.5 & 808.5 & 4.70 & $0.15-2.5$ & 0.62 & $19-57$ & 40.2 & 4373 & $0 \%$ \\
\hline $\begin{array}{l}\text { Village road } \\
\text { near Fugong } \\
\text { FGI }\end{array}$ & $\begin{array}{l}26^{\circ} 55^{\prime} 19^{\prime \prime} \mathrm{N} \\
98^{\circ} 52^{\prime} 02^{\prime \prime} \mathrm{E}\end{array}$ & 1204 & 3 & 783.5 & 6.49 & $0.15-3.0$ & 0.70 & $38-55$ & 45.4 & 12966 & $79.6 \%$ \\
\hline $\begin{array}{l}\text { Village road } \\
\text { about } 2 \mathrm{~km} \\
\text { north of } \\
\text { Fugong FG2 }\end{array}$ & $\begin{array}{l}26^{\circ} 57^{\prime} 07^{\prime \prime} \mathrm{N} \\
98^{\circ} 51^{\prime} 34^{\prime \prime} \mathrm{E}\end{array}$ & 1285 & 3 & 845.5 & 5.35 & $0.15-0.7$ & 0.37 & $35-68$ & 46.0 & 4502 & $74.5 \%$ \\
\hline $\begin{array}{l}\text { Upper section } \\
\text { of village road } \\
45 \mathrm{~km} \text { south of } \\
\text { Fugong SFG1 }\end{array}$ & $\begin{array}{l}26^{\circ} 39^{\prime} 22^{\prime \prime} \mathrm{N} \\
98^{\circ} 53^{\prime} 55^{\prime \prime} \mathrm{E}\end{array}$ & 1259 & 1 & 750 & 5.15 & $0.2-1.8$ & 0.70 & $33-51$ & 42.6 & 2780 & $53.3 \%$ \\
\hline $\begin{array}{l}\text { Lower section } \\
\text { of village road } \\
45 \mathrm{~km} \text { south of } \\
\text { Fugong SFG } 2\end{array}$ & $\begin{array}{l}26^{\circ} 39^{\prime} 22^{\prime \prime} \mathrm{N} \\
98^{\circ} 53^{\prime} 58^{\prime \prime} \mathrm{E}\end{array}$ & 1162 & 1 & 804 & 5.14 & $0.07-3.5$ & 0.64 & $32-66$ & 44.1 & 10838 & $46.4 \%$ \\
\hline
\end{tabular}

and mean annual precipitation is $995 \mathrm{~mm}$, the majority of which falls during the monsoon season (May through to October) (Ghestem et al., 2014). Little to no snow accumulates on the lower portions of the Salween River valley in our study area. Vegetation above and below road excavations varies from steppe shrub to crops, such as rice, corn, and other vegetables. Prior to the 1950s, most sites supported natural forest cover composed of Pinus yunnanensis Franch., Quercus acutissima Carr., Quercus aliena var. acuteserrata, and Castanopsis delavayi (Ghestem et al., 2009).

Based on our field observations, current development in the region appears to be paying little to no attention to road location or construction methods related to the control of mass wasting. Secondary mountain roads are typically constructed by hydraulic shovels, large back hoes, or indiscriminate blasting, and the excavated material is simply disposed onto the side slopes just below the road. The hillsides are characteristically very steep $\left(>30^{\circ}\right)$ with few if any gradient breaks, thus once a landslide initiates along a mid-slope road there is little chance of sediment entrapment on the slope, except near the base of the hillside. Smaller landslides along cut slopes are typically trapped on the road, but this material is often later delivered to streams via surface erosion or it can be incorporated into fill material that eventually fails ( $\mathrm{Si}$ dle et al., 2004, 2011). None of the roads in our study sites had any structural reinforcement except for a recent crude retaining wall constructed on the lower portion of road located several kilometers north of Fugong (FG2). This area was the site of recent mass wasting, just prior to construction, which we documented.

\section{Methodology}

In June 2010, landslides and related sediment delivery to stream and river channels were assessed along seven road segments within the Salween River basin in northwestern Yunnan, China (Table 1). Lengths and widths of landslides were measured with metric tapes where possible or with a laser distance meter (range finder) when slopes were too dan- 


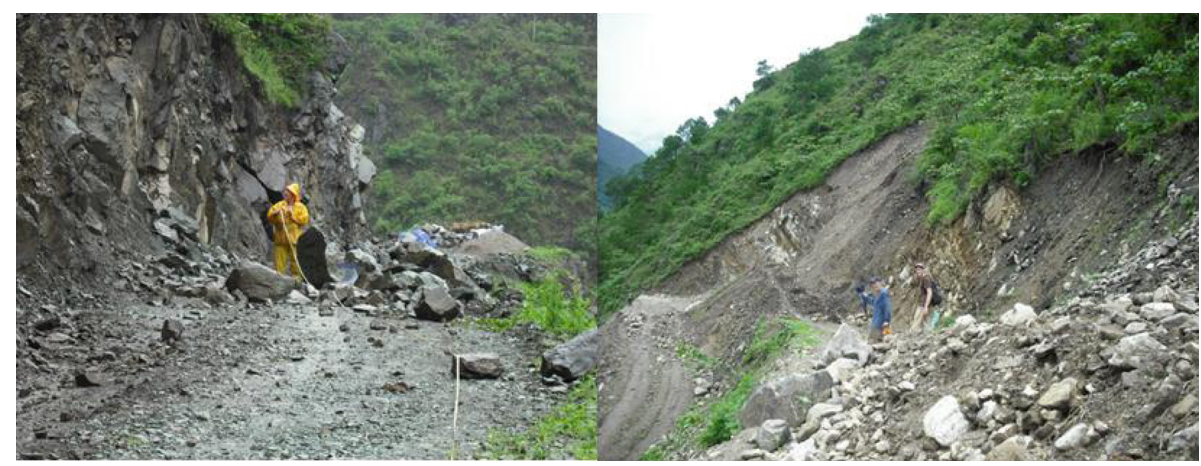

Figure 2. The highest landslide erosion occurred along a 1-year old road (DXD) leading to a remote village and a future hydropower plant just south of Daxingdi, Yunnan.

gerous to traverse. Depths around the flanks of landslides on cut and fill slopes were measured directly where possible and otherwise visually estimated to facilitate calculation of landslide volumes. For some of the cut slope failures, it was clear that the entire landslide mass was trapped on the road; thus, dimensions of the landslide deposit were measured instead of the failure area. Numbers of landslides in cut and fill slopes were adjusted for the age of the road and reported as number per kilometer of road per year.

The calculated landslide volumes were converted to units of mass using an assumed conservative bulk density of $1.3 \mathrm{Mg} \mathrm{m}^{-3}$. For small cut slope and fill slope failures with estimated volumes $>1 \mathrm{~m}^{3}$ and $<3 \mathrm{~m}^{3}$, a volume of $2 \mathrm{~m}^{3}$ was used; failures $\leq 1 \mathrm{~m}^{3}$ were not considered. Landslide volumes were estimated separately for cut and fill slopes for later comparisons. These data were then calculated per unit area based on the width of the road prism and the length of the surveyed road segment divided by the age of the road (or the last widening of the road) - i.e., sediment mass per unit area of road per year. Based on potential measurement errors in estimating landslide volume, we estimate that our volume calculations are within $\pm 10 \%$ of actual values.

To estimate sediment delivery from road-related landslides, we examined the steepness and uniformity (breaks vs. no breaks) of the slope below each slide, as well as any evidence of deposition and the connectivity with the channel. While our visual estimates are somewhat crude approximations of sediment delivery, they are based on geomorphic attributes that control and affect sediment fluxes. At one site (GXK), the channel was relatively distant from the road, thus no connectivity (or sediment delivery) was noted. This does not mean that the sediment would never reach a stream; rather it was deposited on the landscape and could be later entrained by surficial processes, similar to surface erosion from more widespread land use in the region (e.g., Sidle et al., 2006). As such, sediment delivery estimates from roads are conservative. Nevertheless, the direct connectivity of roadrelated landslides with channels proved to be the most efficient and prodigious conduit of sediment delivery.

\section{Results and discussion}

\subsection{Overview of landslide erosion along the different roads}

A total of 312 landslides were measured along about $5 \mathrm{~km}$ of unimproved roads at the seven road survey segments in the Salween River valley. Rates of landslide erosion at all seven road survey segments are extremely high by all standards and comparisons (Table 1). The highest rate of landslide erosion (48 $235 \mathrm{Mg} \mathrm{ha}^{-1} \mathrm{yr}^{-1}$ ) occurred along the 1-year old road leading to a future hydropower plant just south of Daxingdi (DXD, Fig. 2). Based on our knowledge, this is the highest rate of landslide erosion ever reported along mountain roads. The lowest rate of landslide erosion $\left(2780 \mathrm{Mg} \mathrm{ha}^{-1} \mathrm{yr}^{-1}\right.$ ) measured along the upper segment of road located about $45 \mathrm{~km}$ south of Fugong (SFG1, Fig. 3) was still 40-50 times higher than landslide erosion rates associated with logging roads in unstable terrain in the Pacific Northwest USA (Sidle and Ochiai, 2006). Within the continuum of landslide erosion rates that we measured, values from the other five road segments ranged from 3458 to $12966 \mathrm{Mg} \mathrm{ha}^{-1} \mathrm{yr}^{-1}$ (Table 1). These rates are orders of magnitude higher compared to combined landslide and surface erosion rates (on the order of $<3.5 \mathrm{Mg} \mathrm{ha}^{-1} \mathrm{yr}^{-1}$ ) from catchments with predominantly forest or brush cover and interspersed agriculture in Southeast Asia (including parts of China) (Sidle et al., 2006). Additionally, the road-related landslide rates reported herein are slightly higher than those measured along a recently constructed, paved mountain road in the headwaters of the Mekong River basin near Weixi, Yunnan - 1410 to $33450 \mathrm{Mg} \mathrm{ha}^{-1} \mathrm{yr}^{-1}$; average $9610 \mathrm{Mgha}^{-1} \mathrm{yr}^{-1}$ (Sidle et al., 2011).

Aside from the surveyed segment of the village road near Ganxiangke (GXK), which was remote from streams, the delivery of landslide sediment to the Salween River and its tributaries was $>45 \%$. Four of the seven road segments had estimated sediment delivery from roads to streams and rivers exceeding $74 \%$ (Table 1). The DXD road with the highest 


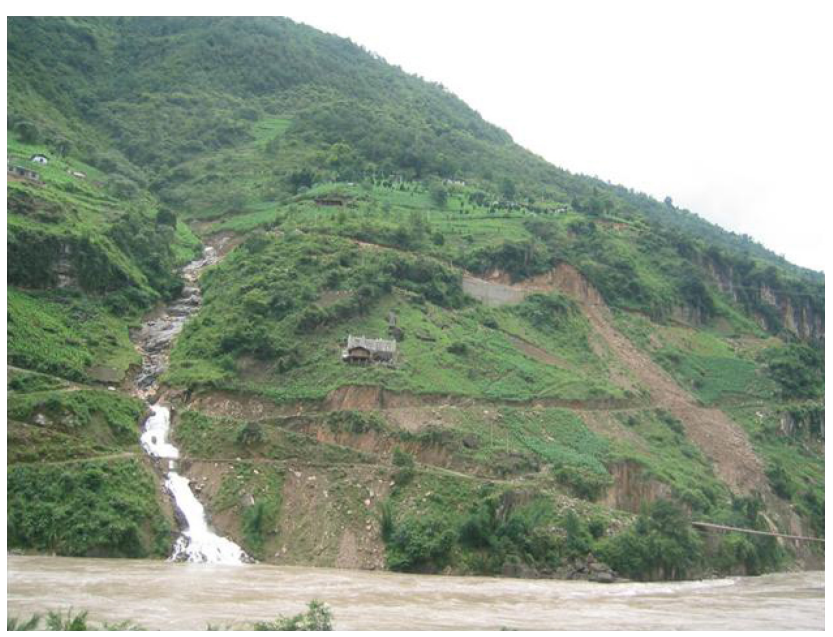

Figure 3. Road leading to a mountain village on the west side of the Salween River about $45 \mathrm{~km}$ south of Fugong. Upper portion of the road had (SFG1) the lowest landslide erosion of all surveyed segments, while the lower portion of the road (SFG2) had fewer numbers of, but larger, cut slope failures. Landslide erosion rates were significantly higher at SFG2 compared to SFG1 - 3.5 times higher for fill slope and 4.4 times higher for cut slope failures. The access bridge across the river is in the lower right corner of the photo.

landslide erosion also had the highest estimated sediment delivery $(86 \%)$; similarly high sediment delivery rates were estimated at WTW (82\%) and FG1 $(80 \%)$ partly due to their proximity to the Salween River (Fig. 4).

The two widest roads (DXD and FG1) had the highest levels of landslide erosion. Wider roads cut into steep terrain disturb a much greater area than narrower roads and tend to destabilize hillslopes to a greater extent (Megahan, 1977; Sidle et al., 1985). Given that all of the roads examined were relatively new (or recently widened), erosion rates reported herein may be higher than longer-term averages. Nevertheless, temporal trends in erosion rates along these mountain roads are complicated by the frequent obliteration and extensive blockage of roads during large storm events (including landslides). Such major disturbances either require new road construction or extensive road widening and excavation, thus perpetuating the cycle of active landsliding.

\subsection{Cut slope versus fill slope landslide erosion}

The relative proportion of landslide erosion along cut slopes and fill slopes varied among sites and was strongly influenced by terrain characteristics, the depth of road cuts into the hillside, and the disposition of fill material. Overall, more landslide sediment was produced from fill slopes $(38170 \mathrm{Mg})$ compared to cut slopes $(29055 \mathrm{Mg}$ ) even though cut slope failures outnumbered fill failures by 235 to 77 (more than a 3:1 ratio). Three examples stand out as having disproportionately higher cut slope or fill slope landslide erosion.
Table 2. Comparison of numbers and mean mass of landslides along cut and fill slopes of the seven monitored road segments.

\begin{tabular}{lccrrr}
\hline Road segment & \multicolumn{2}{c}{$\begin{array}{c}\text { Number of landslides } \\
\left(\mathrm{km}^{-1} \mathrm{yr}^{-1}\right)\end{array}$} & & \multicolumn{2}{c}{$\begin{array}{c}\text { Mean landslide } \\
\text { mass }(\mathrm{Mg})\end{array}$} \\
\cline { 2 - 3 } \cline { 5 - 6 } & Cut slope & Fill slope & & Cut slope & Fill slope \\
\hline DXD & 37.1 & 31.3 & & 94.3 & 1099 \\
WTW & 35.8 & 32.3 & & 13.9 & 39.1 \\
GXG & 44.5 & 1.7 & & 45.7 & 75.7 \\
FG1 & 12.3 & 5.1 & & 612.0 & 168.1 \\
FG2 & 15.0 & 3.5 & & 75.3 & 360.8 \\
SFG1 & 64.0 & 10.7 & & 10.4 & 72.2 \\
SFG2 & 29.9 & 12.4 & & 96.9 & 215.9 \\
7 segments & 33.5 & 11.8 & & 123.7 & 495.7 \\
combined & & & & & \\
\hline
\end{tabular}

The DXD road had a large number $\left(>31.3 \mathrm{~km}^{-1} \mathrm{yr}^{-1}\right)$ and the highest rate $\left(43789 \mathrm{Mg} \mathrm{ha}^{-1} \mathrm{yr}^{-1}\right)$ of road-fill landslides (Table 2; Fig. 5). Of the 27 fill failures that occurred along this monitored segment of road, the average gradient below the road was $44.4^{\circ}$. As such, when unconsolidated rock and soil material from the blasting and excavation was deposited on these steep side slopes, it sometimes failed immediately or shortly thereafter during a large storm. In contrast, two other road segments (FG1 and GXK) had significantly higher (about 9 to 16 times higher) landslide erosion along cut slopes compared to fill slopes (Fig. 5). These differences can be partially attributed to the gentler slope gradients immediately downslope of the road which contributed to the low numbers and volumes of fill slope landslides. The GXK road segment had only 2 fill failures with an average volume of $58 \mathrm{~m}^{3}$, while the FG1 road had 12 failures with an average volume of $124 \mathrm{~m}^{3}$. The WTW road segment, and especially the FG2, SFG1, and SFG2 segments, each had similar levels of cut slope and fill slope landslide erosion (Fig. 5). The greater than 4-fold increase in cut slope landslide volume in SFG2 (lower segment) compared to SFG1 (upper segment) is attributed the deeper road cuts into fractured bedrock in the lower segment (Fig. 3). Much fewer, though larger (mean mass $=96.6 \mathrm{Mg}$ ), failures occurred along rocky cut slopes of SFG2, while more, though much smaller (mean mass $=10.4 \mathrm{Mg}$ ) soil failures occurred along cut slopes of SFG1 (Table 2).

The distribution of all cut slope landslides $(n=235)$ was heavily skewed to small failures $\left(<5 \mathrm{~m}^{3}\right)$ (Fig. 6a). More than $88 \%$ of all cut slope failures were $<100 \mathrm{~m}^{3}$ $(<130 \mathrm{Mg})$. In contrast, fill slope landslides $(n=77)$ followed a more Gaussian size distribution that was only somewhat skewed towards smaller failures (Fig. 6b). About $66 \%$ of all fill slope failures were in the range of $>5$ to $100 \mathrm{~m}^{3}$ and less than $4 \%$ were $<5 \mathrm{~m}^{3}$. Very large $\left(>1100 \mathrm{~m}^{3}\right.$ or $>1430 \mathrm{Mg}$ ) landslides along cut and fill slopes comprised only 2 and $5 \%$ of the respective landslide numbers for these sites (Fig. 6). Nevertheless, the small number of very large 


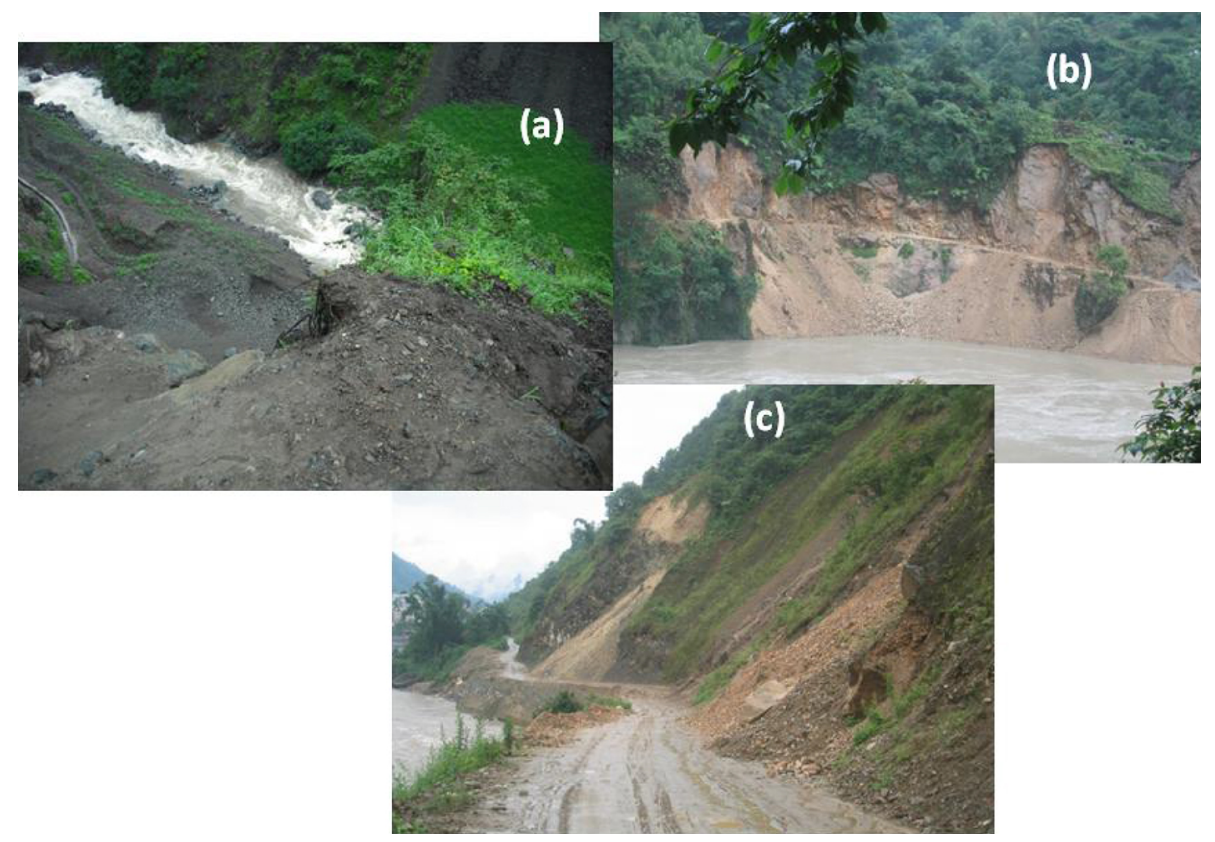

Figure 4. High rates of landslide sediment delivery to the Salween River from the (a) WTW and (b) FG1 roads.

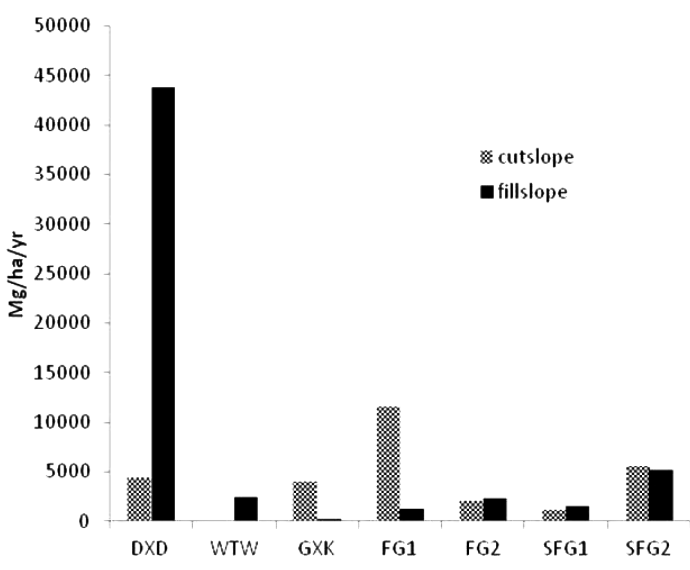

Figure 5. Landslide erosion from cut slopes and fill slopes for the seven surveyed road segments.

( $>1430 \mathrm{Mg}$ ) landslides along cut and fill slopes contributed similar sediment mass (16507 and $16645 \mathrm{Mg}$ ), constituting 56.8 and $43.6 \%$ of the total respective landslide mass. All five of the very large cut slope failures occurred along FG1.

Overall the mean mass of individual fill slope landslides was 4 times higher than cut slope slides; an exception to this trend was FG1 with the five very large cut slope landslides. The widest difference between mean fill and cut slope landslide mass was at DXD with a ratio of 11.6 (Table 2). DXD also had the largest mean mass of fill slope failures, partially attributable to the long, steep, and uniform slopes below the road (Fig. 4a). The sites with the smallest mean landslide masses along cut slopes were SFG1 and WTW (Table 2).
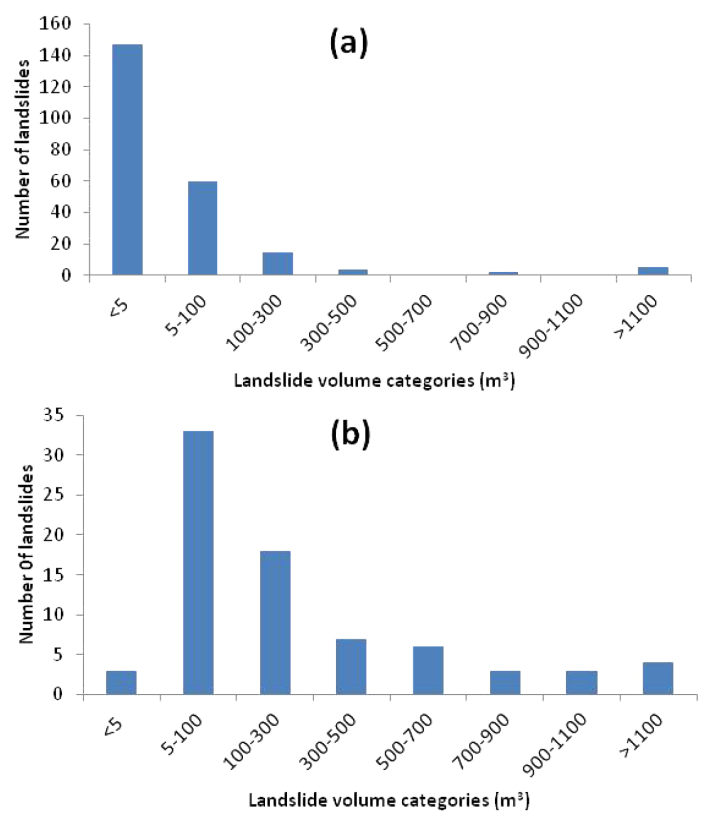

Figure 6. Size distribution for all surveyed landslides from (a) cut slopes $(n=235)$ and (b) fill slopes $(n=77)$.

Overall there were about 3 times more cut slope compared to fill slope landslides, and cut slope landslides were more frequent than fill slope failures at all seven road segments (Table 2). SFG1 had the largest number of cut slope failures, but, as noted, these were small and constituted the second smallest landslide erosion rate of all seven road segments; DXD had a rather large number of sizable cut slope failures. 


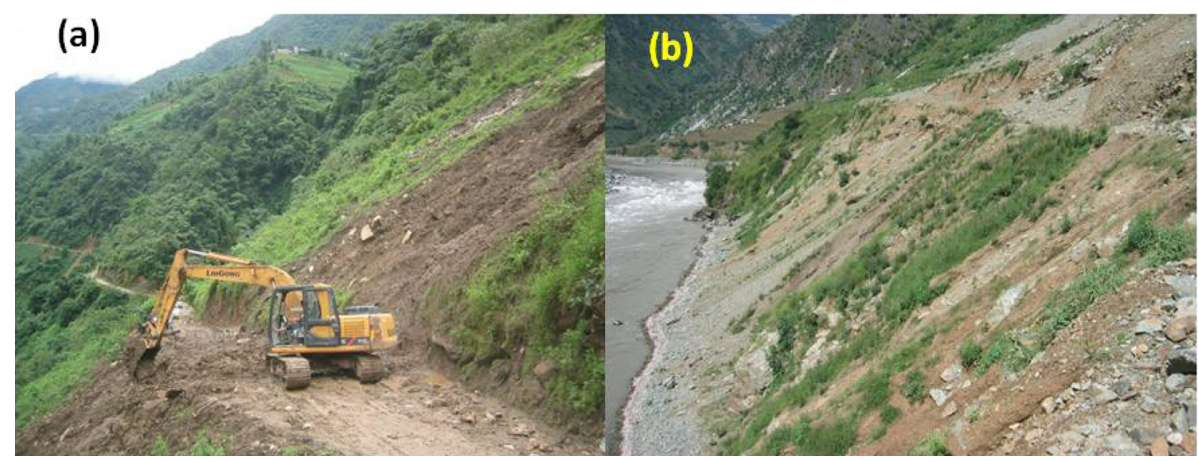

Figure 7. (a) A section of the FG2 road several kilometers north of Fugong that was temporarily closed by a landslide; and (b) secondary road to a small mountain village near Daxingdi (not included in our landslide survey) that was abandoned during construction because of excessive landslides.

WTW and GXK both had high numbers of landslides along cut slopes, but with small to intermediate mean masses (Table 2). Both DXD and WTW had the largest numbers of fill slope failures together with the highest sediment delivery estimates (Tables 1 and 2) - these sites were both proximate to a tributary and the main stem of the Salween River, respectively. Few fill slope failures occurred in FG1 and FG2, and especially in GXK. GXK was situated away from the river and the slope below the road was gentle, containing rice paddy fields.

\subsection{Potential framework for sustainable development}

As a solution to the landslide and associated environmental damages caused by inadequate attention to secondary road location and construction practices in this region, we propose a more sustainable approach that assesses not only the perceived social and economic benefits of these roads, but also the long-term environmental and human welfare impacts. Many of the new roads are inoperable during the rainy season or required extensive excavation or maintenance to remain open (Figs. 2 and 7a). In the worst cases, partially completed roads were abandoned because of persistent landslides leaving a legacy of sedimentation problems with no socioeconomic benefits whatsoever (Fig. 7b). The prolific road-related landslides and associated riverine sedimentation that is occurring within the Salween River basin could push portions of this ecosystem to tipping points where thresholds are breached, causing the collapse of certain ecosystem processes and functions (Sidle et al., 2013). Impacts that could occur in the foreseeable future include (1) extensive areas of degraded site productivity and altered vegetation due to landsliding; (2) degraded downstream water quality and aquatic habitat; (3) transport of contaminated sediments downstream; (4) alteration of the morphology of tributary streams and the main stem of the Salween River; (5) catastrophic debris flows in sediment-laden tributaries; (6) increased flood potential due to reduced channel transmission capacity; and (7) impacts on livelihoods and economies of water users in communities downstream. Some of these effects are already being realized in this region as documented in a nearby tributary of the Mekong River in Yunnan (Sidle et al., 2011).

Moving forward, there is an urgent need to develop a systems-based approach for more sustainable mountain road development before tipping points are reached in these ecosystems. In northwestern Yunnan, this would include detailed landslide hazard assessments prior to road planning and construction activities. Ideally, such analyses should identify the probability of exceeding landslide trigger thresholds (in this area, largely rainfall) coupled with estimates of decreased slope stability associated with different road locations and construction techniques (Fig. 8). This approach would allow for tradeoffs between socioeconomic development and long-term environmental and human welfare impacts by articulating acceptable levels of landslide erosion, with an eye towards avoiding tipping points where site productivity, human welfare, ecological attributes, flooding, and aquatic habit are not compromised in the long term. Tradeoffs for road development could include alternative locations and construction techniques, assessing "stormproofing" roads vs. continual widening and maintenance, considering multiple road uses, incorporating climate change impacts, and reevaluating the necessity of the road. In particular, road location strategies can go a long way towards ameliorating landslide problems; these include (1) optimizing the expected lifetime of the road with uses; (2) ensuring a balance of minimizing road length and minimizing steep gradients; (3) avoiding deep cuts into unstable substrate (especially bedrock dipping parallel to the hillslope); (4) utilizing valley bottom and ridge-top roads whenever feasible; (5) avoiding seasonally wet areas (e.g., hollows); (6) reducing the width of mid-slope roads; (7) avoiding crossing old landslides, particularly undercutting the toe or loading the head of dormant failures; (8) rolling roads to fit hillslope contours and across drainage culverts; and (9) minimizing stream crossings (Megahan et al., 1978; Sidle and Ochiai, 


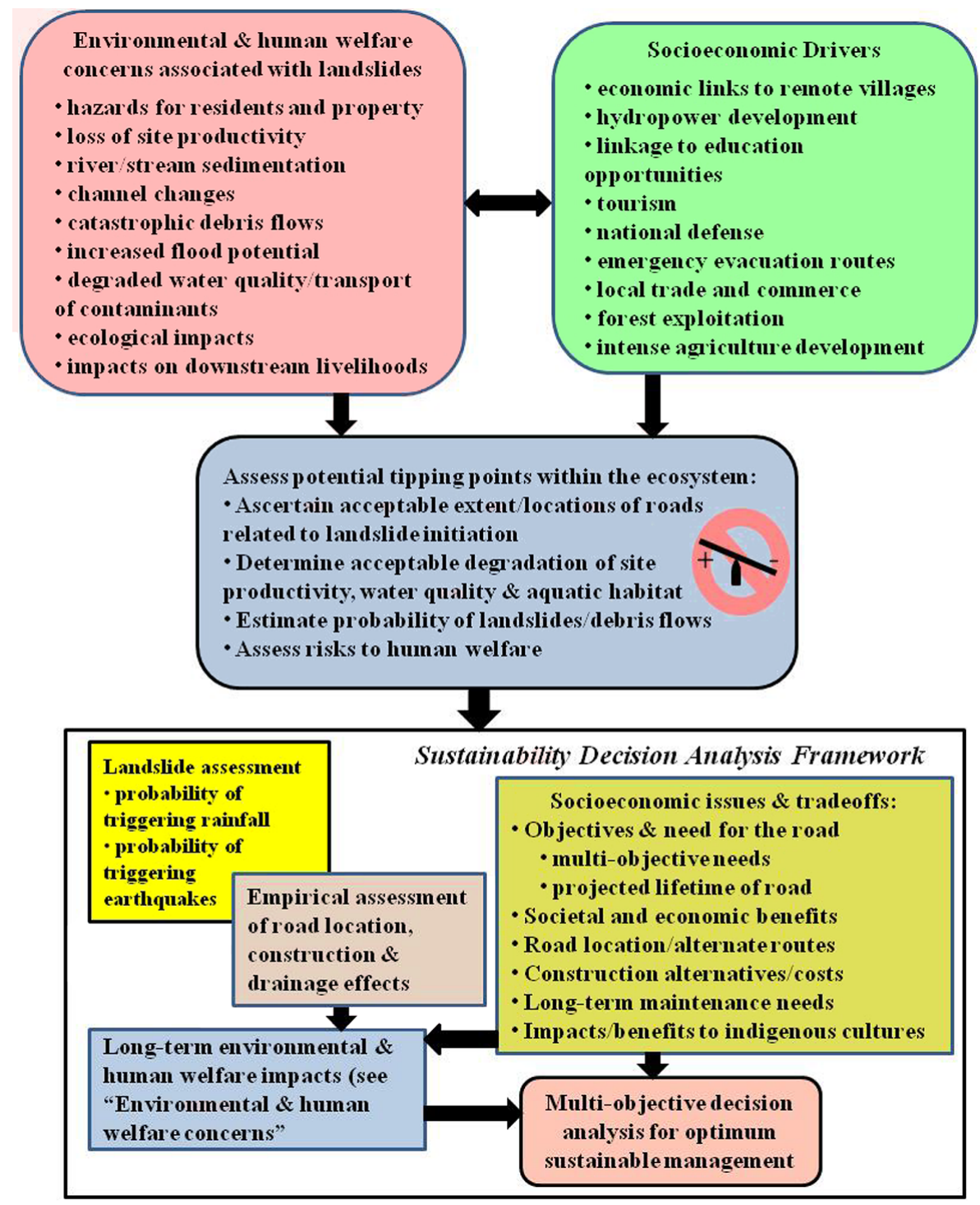

Figure 8. Decision framework for sustainability assessment of mountainous terrain in northwestern Yunnan, China, where extensive road construction is being proposed (modified extensively from Sidle et al., 2013).

2006). Furthermore, planting deep rooted woody vegetation on road fills can enhance long-term stability (e.g., Stokes et al., 2009). Such a systems-based approach that considers all possible road uses and benefits against environmental and human welfare costs (Fig. 8) offers a much more robust and sustainable alternative.

Multi-criteria decision analysis has been applied to similar ecosystem sustainability challenges in which cost/benefit tradeoffs need to be assessed jointly among environmental, social, and economic objectives (e.g., Linkov et al., 2006; Macleod et al., 2007). Throughout much of mountainous Southeast Asia, benefits associated with secondary road development that need quantification include (1) opening economic markets for goods and services produced in remote mountain villages; (2) tourism opportunities; (3) access to hydroelectric generation facilities; (4) educational opportunities; (5) emergency evacuation; and (6) defense of national borders. Cost assessment associated with mountain road development should focus on (1) environmental impacts of hydroelectric power facilities, increased tourism, and forest exploitation; (2) direct impacts of road-related landslides on settlements, sediment loads in rivers, water quality, and aquatic habitat; (3) loss of site productivity on hillslopes affected by landslides; (4) impacts of relatively clean and contaminated sediments in downstream water supplies; (5) effects on channel conveyance, flooding and potential debris flows; (6) siltation of existing reservoirs; and (7) en- 
vironmental consequences of unintended forest exploitation (Fig. 8).

Successful implementation of multi-criteria decision analyses related to road development and associated environmental and natural resources planning in this region will require the engagement of diverse stakeholders with government planning agencies, donor organizations, and science experts. An important aspect of this analysis is the need to incorporate landslide risk associated with extreme events - i.e., storms or other triggers like earthquakes. This will require better spatial and temporal coverage of precipitation in the region. Furthermore, some of the consequences associated with ecosystem tipping points (e.g., floods, debris flows, vegetation changes, aquatic habitat degradation) require a probabilistic approach to assessment of risk. Ecosystem goods and services as well as environmental costs should be appropriately valued; in cases where environmental resources have no apparent market value, alternative techniques can be used (Gregory, 2000; Ananda and Herath, 2009). Inherent to the success of such a decision analysis is the concurrent engagement of government planning agencies that deal with road construction, river management, catchment management (including land use), aquatic habitat and biodiversity, and economic development to resolve interagency conflicts and consider relevant stakeholder opinions together with scientific expertise and evidence (e.g., Macleod et al., 2007).

\section{Summary and conclusions}

Our investigations of landslide erosion along seven different mountain road segments in the upper Salween River basin confirm findings from a prior study (Sidle et al., 2011) in a single tributary of the Mekong River near Weixi, Yunnan. The erosion rates measured along these seven unpaved mountain road segments (2780 to $48238 \mathrm{Mg} \mathrm{ha}^{-1} \mathrm{yr}^{-1}$ ) are higher than the range documented (1410 to $33450 \mathrm{Mg} \mathrm{ha}^{-1} \mathrm{yr}^{-1}$ ) along the newly constructed paved road near Weixi, Yunnan, indicating that such epic levels of landslide erosion and sedimentation are potentially widespread throughout the northern Yunnan region (albeit previously unreported). At four of the seven road segments, more than $74 \%$ of the landslide sediment was estimated to be delivered to tributaries or the main stem of the Salween River. Landslide erosion measured along the road segment just south of Daxingdi (DXD; $>48000 \mathrm{Mg} \mathrm{ha}^{-1} \mathrm{yr}^{-1}$ ) was the highest ever documented along a mountain road corridor.

At all sites, landslides on cut slopes were more numerous, but characteristically smaller than on fill slopes. Where hillslopes were very steep below the excavated road, landslide erosion from fill slopes was greater than from cut slopes. Although few instances of very large landslides $\left(>1100 \mathrm{~m}^{3}\right)$ were recorded, these contributed slightly less than half and slightly more than half of the respective total landslide masses from fill slopes and cut slopes. When blasting was used for road construction and when waste rock and soil were pushed onto steep side slopes, resultant fill slope failures routed large amounts of sediments into channels. In many cases, prudent planning and construction measures could have greatly reduced these landslides and the resultant sediment delivery. At most of these sites, road location and layout did not adequately consider avoidance of wet areas, the need for proper drainage, avoidance of deep cuts into unstable bedrock sequences, minimizing road width, and avoidance of steep and unstable slopes (particularly downslope of the road). With respect to construction, careful removal of earth materials with hydraulic excavators can greatly reduce the disturbed footprint of the road and waste material can be disposed at more stable sites or carefully compacted and incorporated into the road prism.

With the high level of road-related landslide sediment already being transported into the Salween River, a more sustainable approach is needed to assess future road system development. A decision tool is needed that includes a rather detailed analysis of landslide susceptibility based on how thresholds for landslide triggers (i.e., rain events) would be modified by various road locations and different construction techniques. In this systems-based analysis, one could assess tradeoffs amongst socioeconomic benefits of road networks against costs of protecting long-term human welfare, environmental attributes, and site productivity. Multicriteria decision analysis could be employed to properly assess the road-related sediment issue in the context of alternative practices and other land uses. This systems-based approach needs to be embraced by local governments, environmental groups, NGOs, and international organizations and donors, who seem to be focusing almost exclusively on the socioeconomic benefits of roads in this developing mountainous region. Countries located downstream of China within the Salween River basin (Myanmar and Thailand), as well as the other two major river basins in Yunnan (Mekong and Jinsha rivers - Thailand, Cambodia, Laos, and Vietnam), need a sufficient supply of clean water to support livelihoods and development. Trans-boundary sediment issues associated with recent road construction in Yunnan pose serious problems for downstream users. Clearly, a paradigm shift is needed to embrace the concepts of sustainability in conjunction with road development in northwestern Yunnan, as well as in other potentially unstable mountain environments.

Acknowledgements. This project was supported by funding from the French National Institute for Agricultural Research (INRA, Jeune Equipe) and the BMU (Germany) International Climate Initiative funded project "Ecosystems Protecting Infrastructure and Communities" (EPIC, coordinated by IUCN and ProAct, Switzerland). Gratitude is expressed to K.-F. Cao (XTBG and the University of Guangxi, China), W. Ma (Kunming Institute of Botany, China) and F.-X. Mine (ISARA, France), for assistance in field investigations and, logistics and to Lourdes Prieto for preparing the site map. This document has been reviewed in 
accordance with US Environmental Protection Agency policy and approved for publication. The opinions presented herein are those of the authors and do not represent US EPA, ONCFS, INRA, or University of the Sunshine Coast.

Edited by: K. Chang

Reviewed by: four anonymous referees

\section{References}

Ananda, J. and Herath, G.: A critical review of multi-criteria decision making methods with special reference to forest management and planning, Ecol. Econ., 68, 2535-2548, 2009.

Balisacan, A. M.: Averting hunger and food insecurity in Asia, in: Rep. FAO-SEARC Regional Workshop, Policy issues and investment options to avert hunger and food insecurity in Asia, FAO Regional Office for Asia and the Pacific, Bangkok, Thailand, 11-31, 2005.

Bansal, R. C. and Mathur, H. N.: Landslides - the nightmare of hill roads, Soil Conserv. Digest, 4, 36-37, 1976.

Burroughs, E. R., Chalfant, G. R., and Townsend, M. A.: Slope stability in road construction, US Dept. of Interior, BLM, Portland, OR, p. 102, 1976.

Castella, J.-C., Manh, P. H., Kam, S. P., Villano, L., and Tronche, N. R.: Analysis of village accessibility and its impact on land use dynamics in a mountainous province of northern Vietnam, Appl. Geogr., 25, 308-326, 2005.

Chassie, R. G. and Goughnour, R. D.: National highway landslide experience, Highway Focus, 8, 1-9, 1976.

China Road Construction Report: China road construction report, 2007-2008, Beijing Waterwood Technologies CO, Ltd, Beijing, China, p. 62, 2008.

Douglas, I., Bidin, K., Balamurugan, G., Chappell, N. A., Walsh, R. P. D., Greer, T., and Sinun, W.: The role of extreme events in the impacts of selective tropical forestry on erosion during harvesting and recovery phases at Danum Valley, Sabah, Philos. T. Roy. Soc. Lond., 354, 1749-1761, 1999.

Eckholm, E.: Planting for the future: forestry for human needs, Worldwatch Paper 26, Worldwatch Inst., Washington, D.C., 64 pp., 1979.

Fleming, R. W. and Taylor, F. A.: Estimating the cost of landslide damage in the United States, US Geol. Surv. Circular 832, p. 21, 1980.

Ghestem, M., Stokes, A., Cao, K., Ma, W., and Xie, J.: Using vegetation to stabilize steep slopes in Southern China: root biomechanics as a factor in the choice of species, edited by: Thibault, B., in: Proc. 6th Plant Biomechanics Conference, 16-21 November, Cayenne, France, 450-455, 2009.

Ghestem, M., Cao, K. F., Atger, C., Gadenne, C., Ma, W., Osman, N., Leclerc, R., Rowe, N. P., and Stokes, A.: A framework for identifying plants to be used as ecological engineers for fixing soil on unstable slopes, PLoS One, 9, E95876, doi:10.1371/journal.pone.0095876, 2014.

Gregory, R. S.: Valuing environmental options: a case study comparison of multi-attribute and contingent valuation survey methods, Land Econ., 76, 151-173, 2000.

Haigh, M. J.: Landslide prediction and highway maintenance in the Lesser Himalayas, India, Z. Geomorph. NF, 51, 17-37, 1984.
Hettige, H.: When do rural roads benefit the poor and how?, Asian Development Bank, Manila, Philippines, p. 95, 2006.

Holtz, R. D. and Schuster, R. L.: Stabilization of soil slopes, in: Landslides - Investigation and Mitigation, Special Report 247, edited by: Turner, A. K. and Schuster, R. L., Transportation Research Board, National Research Council (US), National Academic Press, Washington, D.C., 439-473, 1996.

Krongkaew, M.: The development of the Greater Mekong Subregion (GMS): real promise or false hope?, J. Asian Econ., 15, 977-998, 2004.

Linkov, I., Satterstrom, F. K., Kiker, G., Seager, T. P., Bridges, T., Gardner, K. H., Rogers, S. H., Belluck, D. A., and Meyer, A.: Multicriteria decision analysis: a comprehensive decision approach for management of contaminated sediments, Risk Anal., 26, 61-78, 2006.

Ma, X., Lu, X. X., van Noordwijk, M., Li, J. T., and Xu, J. C.: Attribution of climate change, vegetation restoration, and engineering measures to the reduction of suspended sediment in the Kejie catchment, southwest China, Hydrol. Earth Syst. Sci., 18, 1979-1994, doi:10.5194/hess-18-1979-2014, 2014.

Macleod, C. J. A., Scholefield, D., and Haygarth, P. M.: Integration for sustainable catchment management, Sci. Total Environ., 373, 591-602, 2007.

Marshall, H.: Consultancy mission report on natural resources management, UNDP/FAO Consultancy Mission Report SPPD DP/MYA/98/003, FAO, Bangkok, 1999.

Megahan, W. F.: Reducing erosional impacts of roads, in: Guidelines for Watershed management, FAO Conservation Guide, UN Food and Argic. Organ., Rome, 237-251, 1977.

Megahan, W. F., Day, N. F., and Bliss, T. M.: Landslide occurrence in the western and central Northern Rocky Mountain physiographic province in Idaho, in: Proc. 5th North Am. Forest Soils Conf., Colo. State Univ., Ft. Collins, CO, 116-139, 1978.

Mills, K.: Forest roads, drainage, and sediment delivery in the Kilchis River watershed. Oregon Dept. of Forestry, Salem, OR, p. 21, 1997.

Nyaupane, G. P., Morais, D. B., and Dowler, L.: The role of community involvement and number/type of visitors on tourism impacts: A controlled comparison of Annapurna, Nepal and Northwest Yunnan, China, Tourism Manage., 27, 1373-1385, 2006.

Rice, R. M.: Erosion on logging roads in Redwood Creek, northwestern California, J. Am Water Resour. Assoc., 35, 1171-1180, 1999.

Sakakibara, H., Kajitani, Y., and Okada, N.: Road network robustness for avoiding functional isolation in disasters, J. Transport Eng.-ASCE, 130, 560-567, 2004.

Sidle, R. C.: Comments on "Predicting soil erosion for alternative land uses" by E. Wang, C. Xin, J. R. Williams, and C. Xu, J. Environ. Qual., 35, 459-467, 2006.

Sidle, R. C. and Ochiai, H.: Landslides: Processes, Prediction, and Land Use, Am. Geophysical Union, Water Resour Monogr No. 18, AGU, Washington, D.C., p. 312, 2006.

Sidle, R. C. and Ziegler, A. D.: The dilemma of mountain roads, Nat. Geosci., 5, 437-438, doi:10.1038/ngeo1512, 2012.

Sidle, R. C., Pearce, A. J., and O'Loughlin, C. L.: Hillslope Stability and Land Use, Am. Geophysical Union, Water Resour. Monogr. 11, Washington, D.C., p. 140, 1985. 
Sidle, R. C., Sasaki, S., Otsuki, M., Noguchi, S., and Abdul Rahim, N.: Sediment pathways in a tropical forest: effects of logging roads and skid trails, Hydrol. Process., 18, 703-720, 2004.

Sidle, R. C., Ziegler, A. D., Negishi, J. N., Abdul Rahim, N., Siew, R., and Turkelboom, F.: Erosion processes in steep terrain Truths, myths, and uncertainties related to forest management in Southeast Asia, Forest Ecol. Manage., 224, 199-225, 2006.

Sidle, R. C., Ziegler, A. D., and Vogler, J. B.: Contemporary changes in open water surface area of Lake Inle, Myanmar: possible causes, Sustain. Sci., 2, 55-65, 2007.

Sidle, R. C., Furuichi, T., and Kono, Y.: Unprecedented rates of landslide and surface erosion along a newly constructed road in Yunnan, China, Nat. Hazards, 57, 313-326, 2011.

Sidle, R. C., Benson, W. H., Carriger, J. F., and Kamai, T.: A broader perspective on ecosystem sustainability: consequences for decision-making, P. Natl. Acad. Sci. USA, 110, 9291-9208, 2013.

Stokes, A., Atger, C., Bengough, A. G., Fourcaud, T., and Sidle, R. C.: Desirable plant root traits for protecting natural and engineered slopes against landslides, Plant Soil, 324, 1-30, 2009.

Su, Y., Xu, J., Wilkes, A., Lu, J., Li, Q., Fu, Y., Ma, X., and Grumbine, R. E.: Coping with climate-induced water stresses through time and space in the mountains of Southwest China, Reg. Environ. Change, 12, 855-866, 2012.

Tullos, D. D., Foster-Moore, E., Magee, D., Tilt, B., Wolf, A. T., Schmitt, E., Gassert, F., and Kibler, K.: Biophysical, socioeconomic, and geopolitical vulnerabilities to hydropower development on the Nu River, China, Ecol. Soc., 18, 16, doi:10.5751/ES05465-180316, 2013.

UNESCO: Programme of Man and the Biosphere, Working Group on Project 6: Impact of human activities on mountain and tundra ecosystems, MAP Report Series No. 14, Paris, 20-21, 1974.

UNESCO: Decisions adopted by the 27th session of the World Heritage Committee in 2003, WHC-03/27.COM/24, UNESCO World Heritage Centre, Paris, p. 179, 2003.
Urban, F., Nordensvärd, J., Khatri, D., and Wang, Y.: An analysis of China's investiment in hydropower sector in the Greater Mekong Sub-Region, Environ. Dev. Sustain., 15, 301-324, 2013.

van de Walle, D.: Choosing rural road investiments to help reduce poverty, World Develop., 30, 575-589, 2002.

Volk, P., Heymann, J., Saradeth, S., Bechstedt, H. D., Löffler, E., Stuurman, W., Aiblinger, S., Carl, S., Küpper, A., Lamprecht, S., Ringenberg, H., and Schönberg, A.: Mapping and land use planning for watershed management, Final report for the government of Myanmar, Ministry of Forestry, GAF, Munich, 1996.

Wasson, R. J., Juyal, N., Jaiswal, M., McCulloch, M., Sarin, M. M., Jain, V., Srivastava, P., and Singhvi, A. K.: The mountainlowland debate: Deforestation and sediment transport in the upper Ganga catchment, J. Environ. Manage., 88, 53-61, 2008.

Wemple, B. C., Swanson, F. J., and Jones, J. A.: Forest roads and geomorphic process interactions, Cascade Range, Oregon, Earth Surf. Proc. Land., 26, 191-204, 2001.

Ziegler, A. D., Giambelluca, T. W., Sutherland, R. A., Nullet, M. A., Yarnasarn, S., Pinthong, J., Preechapanya, P., and Jaiaree, S.: Toward understanding the cumulative impacts of roads in upland agricultural watersheds of northern Thailand, Agric, Ecosyst. Environ., 104, 145-158, 2004.

Ziegler, A. D., Bruun, T. B., Guardiola-Claramonte, M., Giambelluca, T. W., Lawrence, D., and Nguyen, T. L.: Environmental consequences of the demise in swidden cultivation in montane mainland Southeast Asia: hydrology and geomorphology, Human Ecol., 37, 361-373, 2009.

Ziegler, A. D., Sidle, R. C., Song, M. S., Ang, Z. J., and Duangnamon, D.: Towards better design and management of tsunami evacuation routes: a case study of Ao Jak Beach Road, Geol. Soc. London Special Publ., London, UK, 2012. 